\title{
EFFECT OF CASING MATERIAL MANAGEMENT ON YIELD AND YIELD ATTRIBUTES OF MILKY WHITE MUSHROOM (CALOCYBE INDICA)
}

\author{
Md. Ferdaus Ahmed 1, ${ }^{*}{ }^{\square}$, Md. Jahedur Rahman 1, Md. Nazrul Islam ${ }^{1}$, Md. Jafar \\ Ullah ${ }^{3}$, Nirod Chandra Sarker 4 \\ ${ }_{1}^{1}$ Department of Horticulture, Sher-e-Bangla Agricultural University, Bangladesh \\ 2 Department of Agricultural Extension, Khamarbari, Dhaka, Bangladesh \\ ${ }^{3}$ Department of Agronomy, Sher-e-Bangla Agricultural University, Bangladesh \\ ${ }^{4}$ Mushroom Development Institute, Savar Dhaka, Bangladesh
}

DOI: https://doi.org/10.29121/granthaalayah.v8.i10.2020.1880

Article Type: Research Article

Article Citation: Md. Ferdaus Ahmed, Md. Jahedur Rahman, Md. Nazrul Islam, Md. Jafar Ullah, and Nirod Chandra Sarker. (2020). EFFECT OF CASING MATERIAL MANAGEMENT ON YIELD AND YIELD ATTRIBUTES OF MILKY WHITE MUSHROOM (CALOCYBE INDICA). International Journal of Research -GRANTHAALAYAH, 8(10), 333-337

https://doi.org/10.29121/granthaa layah.v8.i10.2020.1880

Received Date: 13 October 2020

Accepted Date: 31 October 2020

Keywords:

Casing Material

Management Technique

Milky White Mushroom (Calocybe Indica)

\section{ABSTRACT}

General practice in Bangladesh is, after harvest producers leave the non-effective fruiting body of milky white mushroom in the spawn packet as it is. But every fruiting body primordia take some nutrient from the substrate, and the dried \& rotten primordia may encourage other competitive fungi or harmful microorganism to grow on the upper surface of the substrate which may affect the fruiting body formation and yield in the subsequent flushes. Therefore, the present study was under taken to know the effect of casing material management technique on yield and yield attributes of milky white mushroom. Five different casing material management technique were practiced in this experiment, such as $\mathrm{T}_{1}=$ removal of dried non effective fruiting bodies after each harvest; $\mathrm{T}_{2}=$ removal of dried non effective fruiting bodies and filling the casing hole with fresh casing material after each harvest; $\mathrm{T}_{3}=$ scraping the upper surface of the substrate after each harvest; $\mathrm{T}_{4}=$ scraping the upper surface of the substrate and adding 10\% fresh casing material after each harvest; and $\mathrm{T}_{5}=$ no disturbance of the casing material (control). Number of effective fruiting body (NEFB), number of flushes, days to total harvest and size of fruiting body were significantly affected by casing material management technique but economic yield and biological efficiency among the treatments were insignificant. Considering all the parameters removal of dried non effective fruiting bodies and filling the casing hole with fresh casing material after each harvest $\left(\mathrm{T}_{2}\right)$ was the best technique for casing material management.

\section{INTRODUCTION}

Casing is an important cultural practice of milky white mushroom cultivation. Casing means covering the cultivation substrate with a layer of soil or soil like material after spawn run which enhances the transformation of vegetative stage to reproductive stage (Pani, 2012; Suess and Curtis, 2009). Casing the surface of composted substrate fully colonized by mycelium of mushroom is an essential function in stimulation and promoting the development of fruit bodies (Farsi et al., 2011). Recent studies on the constraints in the cultivation of milky mushroom indicated casing is the most important factor

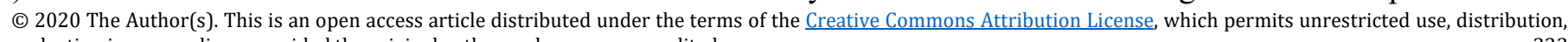
and reproduction in any medium, provided the original author and source are credited. 
affecting the yield. The production of Calocybe indica depends on top dressing after the substrate has been fully colonized with mycelium. After complete mycelia formation casing is done to provide a reservoir of water for the developing fruiting body.

Milky white mushroom produces numerous fruiting body primordia during first flush and decreases in the following flushes. Among the fruiting body primordia some are grown vigorously to produce effective fruiting body and rest of the primordia remain as non-effective fruiting body which ultimately become dry or rotten. General practice in our country is, after harvest producers leave the non-effective fruiting body in the spawn packet as it is. But every fruiting body primordia take some nutrient from the substrate, and the dried and rotten primordia may encourage other competitive fungi or harmful microorganism to grow on the upper surface of the substrate which may affect the fruiting body formation and yield in the subsequent flushes. Therefore, the present study was under taken to know the effect of casing material management on the yield and biological efficiency of milky white mushroom.

\section{MATERIALS AND METHODS}

The experiment was conducted at Mushroom Development Institute (MDI), Department of Agricultural Extension, Savar, Dhaka, Bangladesh from May to July 2020.

\subsection{TREATMENTS}

Five different casing material management techniques were practiced in this experiment such as $\mathrm{T}_{1}=$ removal of dried non effective fruiting bodies after each harvest; $\mathrm{T}_{2}=$ removal of dried non effective fruiting bodies and filling the casing hole with fresh casing material after each harvest; $T_{3}=$ scraping the upper surface of the substrate after each harvest; $T_{4}=$ scraping the upper surface of the substrate and adding $10 \%$ fresh casing material after each harvest; and $\mathrm{T}_{5}=$ no disturbance of the casing material (control).

\subsection{SPAWN PREPARATION}

Rice straw was used for the cultivation of milky white mushroom. The straw was chopped to convenient length of 2.5 to $5 \mathrm{~cm}$. The substrate was mixed with appropriate amount of water and then filled in net bag. The net bag filled with substrate were placed in the sterilization cum inoculation chamber. Door of the chamber was closed and tightened with the help of screws. Water heater was turned on to produce steam that flows in to the chamber. When the temperature of the chamber rises to $60^{\circ} \mathrm{C}$, the steam flow was adjusted to maintain a constant temperature of $70^{\circ} \mathrm{C}-80^{\circ} \mathrm{C}$ up to 90 minutes. After 90 minutes water heater was turned off and kept it for about 20 hours. After 20 hours substrate was taken out and used for preparation of spawn packet. Pasteurized substrate was filled into the polythene bags (12"x16") and inoculated with $20 \%$ sawdust mother culture by thorough mixing. Then the spawn packets were transferred to the culture house for mycelium run. After 16-25 days the substrate was completely colonized by the mycelium and polythene cover was opened.

\subsection{CASING AND AFTER CARE}

Loamy soil was used as casing material and was sterilized at $65^{\circ} \mathrm{C}$ for 4 hours. Casing material was covered over the mycelium on the substrate up to $4 \mathrm{~cm}$ thickness. Watering was done at regular interval to maintain moisture at 60 to $70 \%$. Primordia initiated at 7-14 days and developed in to fruiting bodies.

\subsection{CASING MATERIAL MANAGEMENT}

In $T_{1}$, after each harvest non effective fruiting bodies were removed by hand picking; in $T_{2}$, non effective fruiting bodies were removed and the holes of casing material were filled with fresh casing material after each harvest; in $T_{3}$, after each harvest upper surface of the substrate was scraped gently with finger; in case of $T_{4}$, after each harvest upper surface of the substrate was scraped gently with finger and added $10 \%$ fresh casing material; and in $\mathrm{T}_{5}$, casing material was allowed to remain undisturbed.

The fruiting bodies were harvested at 7-8 days of primordia initiation and data were collected on days to primordia initiation, length of stalk, diameter of stalk, diameter of pileus, thickness of pileus, number of effective fruiting body 
(NEFB), number of flushes, days to total harvest, weight of fruiting, yield and biological efficiency (BE). The BE was measured by the formula;

$$
\mathrm{BE}=\frac{\text { Fresh weight of mushroom }}{--\mathrm{-} \text { Dry weight of substrate. }}
$$

\subsection{DATA ANALYSIS}

The experiment was laid out in Completely Randomized Design (CRD) with 4 replications. The data were statistically analyzed following SPSS (version 20.0) computer program. Difference among the treatment means were determined by Tukey's Test (Tukey, 1977) at $P \leq 0.05$.

\section{RESULT AND DISCUSSION}

\subsection{NUMBER OF EFFECTIVE FRUITING BODY, NUMBER OF FLUSHES AND DAYS TO TOTAL HARVEST}

Number of effective fruiting body (NEFB), number of flushes and days to total harvest of milky white mushroom was significantly affected by casing material management technique (Table-1). Both number of effective fruiting body (8.83) and number of flushes (2.81) were highest when non effective dried fruiting bodies were removed after each harvest $\left(\mathrm{T}_{1}\right)$ and were lowest ( $4.65 \& 1.63)$ when upper surface of the substrate was scrapped with hand and $10 \%$ fresh casing material was added after each harvest $\left(\mathrm{T}_{4}\right)$. Highest time (65.08 days) was required for total harvest (spawning to last harvest) of milky white mushroom when upper surface of the substrate was scrapped after each harvest $\left(\mathrm{T}_{3}\right)$ and lowest time $(53.15$ days) was required when the casing material was allowed to remain undisturbed $\left(\mathrm{T}_{5}\right)$. Days to spawn run and days to fruiting body primordial initiation were also significantly varied in this study (Table-1). Shortest time (15.15 days) was required for completing spawn run and longest time (11.15 days) was required for fruiting body primordial initiation in $\mathrm{T}_{4}$ but longest time (23.95 days) was required for completing spawn run in $T_{3}$ and shortest time ( 7.73 days) was required for fruiting body primordial initiation in $\mathrm{T}_{1}$. This result supports the findings of Amin et al. (2010) who reported that number of effective fruiting body of milky white mushroom varied from 1.57 to 7.75 and total days for harvest varied from 44.0 to 64.75 days as affected by casing material thickness.

Table 1: Effect of casing material management technique on number of effective fruiting body, number of flushes and days to total harvest of milky white mushroom

\begin{tabular}{|c|c|c|c|c|c|}
\hline Treatments & $\begin{array}{c}\text { Days to } \\
\text { spawn run }\end{array}$ & $\begin{array}{c}\text { Days to pin head } \\
\text { formation }\end{array}$ & $\begin{array}{c}\text { Number of effective } \\
\text { fruiting body }\end{array}$ & $\begin{array}{c}\text { Number of } \\
\text { flushes }\end{array}$ & $\begin{array}{c}\text { Days to total } \\
\text { harvest }\end{array}$ \\
\hline $\mathrm{T}_{1}$ & $20.03 \mathrm{~b}$ & $7.73 \mathrm{~d}$ & $8.83 \mathrm{a}$ & $2.81 \mathrm{a}$ & $62.95 \mathrm{a}$ \\
\hline $\mathrm{T}_{2}$ & $20.08 \mathrm{~b}$ & $8.15 \mathrm{~cd}$ & $8.08 \mathrm{ab}$ & $2.44 \mathrm{ab}$ & $60.70 \mathrm{a}$ \\
\hline $\mathrm{T}_{3}$ & $23.95 \mathrm{a}$ & $9.28 \mathrm{~b}$ & $5.65 \mathrm{bc}$ & $1.94 \mathrm{bc}$ & $65.08 \mathrm{a}$ \\
\hline $\mathrm{T}_{4}$ & $15.15 \mathrm{~d}$ & $11.15 \mathrm{a}$ & $4.65 \mathrm{c}$ & $1.63 \mathrm{c}$ & $55.15 \mathrm{~b}$ \\
\hline $\mathrm{T}_{5}$ & $17.15 \mathrm{c}$ & $8.60 \mathrm{c}$ & $7.28 \mathrm{abc}$ & $2.44 \mathrm{ab}$ & $53.15 \mathrm{~b}$ \\
\hline $\mathrm{P}$ & $<0.001$ & $<0.001$ & 0.002 & 0.001 & $<0.001$ \\
\hline
\end{tabular}

In column figures having same letters do not differ significantly at $5 \%$ level according to Tukey's test.

Size of fruiting body, yield and biological efficiency: Length of stalk, diameter of pileus and thickness of pileus were significantly influenced by casing material management technique but diameter of stalk was not affected (Table-2). Length of stalk $(11.18 \mathrm{~cm})$, diameter of pileus $(7.48 \mathrm{~cm})$ and thickness of pileus $(2.75 \mathrm{~cm})$ was highest when upper surface of the substrate was scrapped and 10\% fresh casing material was added after each harvest $\left(\mathrm{T}_{4}\right)$ but diameter of stalk $(2.95 \mathrm{~cm})$ was highest when upper surface of the substrate was scrapped after each harvest $\left(\mathrm{T}_{3}\right)$ which was similar to other treatments. Stalk length $(8.63 \mathrm{~cm})$, pileus diameter $(5.23 \mathrm{~cm})$ and pileus thickness $(2.15 \mathrm{~cm})$ were lowest when non effective dried fruiting bodies were removed after each harvest $\left(T_{1}\right)$ but stalk diameter $(2.65 \mathrm{~cm})$ was lowest when the casing material was allowed to remain undisturbed $\left(\mathrm{T}_{5}\right)$. Similar result was reported by Amin et al. (2010) who recorded stalk length ranges from 2.68 to $9.51 \mathrm{~cm}$, stalk diameter from 2.39 to $3.05 \mathrm{~cm}$ and pileus diameter from 5.05 to $7.75 \mathrm{~cm}$ as affected by casing material thickness. 
Average weight of fruiting body was significantly affected by casing material management technique but variation in yield and biological efficiency among the treatments were insignificant (Table-2). Average weight per fruiting body was highest $(85.93 \mathrm{~g})$ when upper surface of the substrate was scrapped and $10 \%$ fresh casing material was added after each harvest $\left(\mathrm{T}_{4}\right)$ and was lowest $(41.65 \mathrm{~g})$ when non effective dried fruiting bodies were removed after each harvest $\left(\mathrm{T}_{1}\right)$. Highest yield $(400.75 \mathrm{~g})$ and biological efficiency $(96.85 \%)$ were recorded in treatment $\mathrm{T}_{2}$ and lowest $(321.90 \mathrm{~g} \mathrm{\&} 77.58 \%)$ in $\mathrm{T}_{5}$. This result is comparable with the findings of Kerketta et al. (2018) who recorded average weight of sporophore of different C. indica strain from 54 to $82 \mathrm{~g}$.

Table 2: Effect of casing material management technique on size of fruiting body, economic yield and biological efficiency of milky white mushroom

\begin{tabular}{|c|c|c|c|c|c|c|c|}
\hline Treatments & $\begin{array}{c}\text { Length of } \\
\text { stalk }(\mathrm{cm})\end{array}$ & $\begin{array}{c}\text { Diameter of } \\
\text { stalk }(\mathrm{cm})\end{array}$ & $\begin{array}{c}\text { Diameter of } \\
\text { pileus }(\mathrm{cm})\end{array}$ & $\begin{array}{c}\text { Thickness of } \\
\text { pileus }(\mathrm{cm})\end{array}$ & $\begin{array}{c}\text { Weight of } \\
\text { fruiting } \\
\text { body }(\mathrm{g})\end{array}$ & $\begin{array}{c}\text { Economic } \\
\text { yield } \\
\text { (g/packet) }\end{array}$ & $\begin{array}{c}\text { Biological } \\
\text { efficiency } \\
(\%)\end{array}$ \\
\hline $\mathrm{T}_{1}$ & $8.63 \mathrm{c}$ & $2.75 \mathrm{a}$ & $5.23 \mathrm{c}$ & $2.15 \mathrm{~b}$ & $41.65 \mathrm{c}$ & $340.25 \mathrm{a}$ & $82.00 \mathrm{a}$ \\
\hline $\mathrm{T}_{2}$ & $10.13 \mathrm{ab}$ & $2.85 \mathrm{a}$ & $6.18 \mathrm{abc}$ & $2.35 \mathrm{~b}$ & $52.40 \mathrm{ab}$ & $400.75 \mathrm{a}$ & $96.58 \mathrm{a}$ \\
\hline $\mathrm{T}_{3}$ & $9.85 \mathrm{abc}$ & $2.95 \mathrm{a}$ & $7.00 \mathrm{a}$ & $2.73 \mathrm{a}$ & $67.28 \mathrm{ab}$ & $341.33 \mathrm{a}$ & $82.28 \mathrm{a}$ \\
\hline $\mathrm{T}_{4}$ & $11.18 \mathrm{a}$ & $2.85 \mathrm{a}$ & $7.48 \mathrm{a}$ & $2.75 \mathrm{a}$ & $85.93 \mathrm{a}$ & $327.13 \mathrm{a}$ & $76.58 \mathrm{a}$ \\
\hline $\mathrm{T}_{5}$ & $9.40 \mathrm{bc}$ & $2.65 \mathrm{a}$ & $5.55 \mathrm{bc}$ & $2.23 \mathrm{~b}$ & $47.23 \mathrm{c}$ & $321.90 \mathrm{a}$ & $77.58 \mathrm{a}$ \\
\hline $\mathrm{P}$ & 0.002 & 0.406 & 0.003 & 0.001 & 0.017 & 0.225 & 0.136 \\
\hline
\end{tabular}

In column figures having same letters do not differ significantly at 5\% level according to Tukey’s test.

\subsection{NUMBER OF EFFECTIVE FRUITING BODY AND YIELD PER FLUSH}

Number of effective fruiting body (NEFB) was significantly varied among the treatments in $2^{\text {nd }}$ flush but in $1^{\text {st }}, 3^{\text {rd }}$ and $4^{\text {th }}$ flush variation in NEFB among the treatments were insignificant (Table-3). Highest NEFB were recorded in $T_{1}$ both in $1^{\text {st }}$ and $2^{\text {nd }}$ flush $(4.31 \& 3.56)$ but it was highest in $\mathrm{T}_{2}(1.06)$ and $\mathrm{T}_{5}(0.38)$ in $3^{\text {rd }}$ flush and $4^{\text {th }}$ flush respectively.

Significant variation of economic yield among the treatments were observed in $1^{\text {st }}, 2^{\text {nd }}$ and $3^{\text {rd }}$ flush but in $4^{\text {th }}$ flush it was insignificant (Table-3). $\mathrm{T}_{4}$ gave the highest yield in $1^{\text {st }}$ flush $(294.75 \mathrm{~g})$ but it was lowest in $2^{\text {nd }}$ flush $(33.63 \mathrm{~g})$. No fruiting body was recorded in $3^{\text {rd }}$ and $4^{\text {th }}$ flush in $\mathrm{T}_{4}$. $\mathrm{T}_{1}$ produces highest yield in $2^{\text {nd }}$ flush $(115 \mathrm{~g})$ but $\mathrm{T}_{5}$ in $3^{\text {rd }}(38.94 \mathrm{~g})$ and $4^{\text {th }}$ flush $(14.13 \mathrm{~g})$. Economic yield per flush was varied significantly and it was decreased gradually from $1^{\text {st }}$ flush to the subsequent flushes. This result is comparable with the findings of Patel and Trivedi (2016) who also recorded gradual decrease in yield from $1^{\text {st }}$ harvest to the subsequent harvest of $C$. indica.

Table 3: Flush wise number of effective fruiting body, weight of fruiting body and yield as affected by casing material management technique

\begin{tabular}{|c|c|c|c|c|c|c|c|c|}
\hline \multirow{2}{*}{ Treatments } & \multicolumn{4}{|c|}{ Number of fruiting body per flush } & \multicolumn{4}{c|}{ Economic yield (g) per flush } \\
\cline { 2 - 9 } & $1^{\text {st flush }}$ & $2^{\text {nd }}$ flush & $3^{\text {rd }}$ flush & $4^{\text {th }}$ flush & $1^{\text {st }}$ flush & $2^{\text {nd }}$ flush & $3^{\text {rd }}$ flush & $4^{\text {th }}$ flush \\
\hline $\mathrm{T}_{1}$ & $4.31 \mathrm{a}$ & $3.56 \mathrm{a}$ & $1.06 \mathrm{a}$ & $0.06 \mathrm{a}$ & $202.13 \mathrm{~b}$ & $115.0 \mathrm{a}$ & $22.63 \mathrm{ab}$ & $1.63 \mathrm{a}$ \\
\hline $\mathrm{T}_{2}$ & $3.75 \mathrm{a}$ & $2.94 \mathrm{ab}$ & $1.06 \mathrm{a}$ & $0.25 \mathrm{a}$ & $278.38 \mathrm{a}$ & $92.38 \mathrm{ab}$ & $24.00 \mathrm{ab}$ & $6.00 \mathrm{a}$ \\
\hline $\mathrm{T}_{3}$ & $3.44 \mathrm{a}$ & $2.06 \mathrm{bc}$ & $0.13 \mathrm{a}$ & $0.00 \mathrm{a}$ & $284.88 \mathrm{a}$ & $53.19 \mathrm{c}$ & $3.38 \mathrm{ab}$ & $0.00 \mathrm{a}$ \\
\hline $\mathrm{T}_{4}$ & $3.38 \mathrm{a}$ & $1.19 \mathrm{c}$ & $0.00 \mathrm{a}$ & $0.00 \mathrm{a}$ & $294.75 \mathrm{a}$ & $33.63 \mathrm{c}$ & $0.00 \mathrm{~b}$ & $0.00 \mathrm{a}$ \\
\hline $\mathrm{T}_{5}$ & $3.56 \mathrm{a}$ & $2.13 \mathrm{bc}$ & $0.81 \mathrm{a}$ & $0.38 \mathrm{a}$ & $199.63 \mathrm{~b}$ & $64.94 \mathrm{bc}$ & $38.94 \mathrm{a}$ & $14.13 \mathrm{a}$ \\
\hline $\mathrm{P}$ & 0.580 & $<0.001$ & 0.037 & 0.377 & 0.005 & $<0.001$ & 0.038 & 0.246 \\
\hline
\end{tabular}

In column figures having same letters do not differ significantly at $5 \%$ level according to Tukey's test.

Variation in average weight of fruiting body among the treatments were insignificant during all the flushes (Figure-1). But fruiting body weight was significantly varied among the flushes and it was gradually decreased from $1^{\text {st }}$ flush to the subsequent flushes. Fruiting body weight was highest in $\mathrm{T}_{4}$ during $1^{\text {st }}$ flush $(94.98 \mathrm{~g})$, in $\mathrm{T}_{1}$ during $2^{\text {nd }}$ flush $(32.46 \mathrm{~g})$ and in $\mathrm{T}_{5}$ during $3^{\text {rd }}(25.29 \mathrm{~g}) \& 4^{\text {th }}(19.0 \mathrm{~g})$ flush. This result is comparable with the findings of Patel and Trivedi (2016) who also recorded gradual decrease in yield from $1^{\text {st }}$ harvest to the subsequent flushes. 
Md. Ferdaus Ahmed, Md. Jahedur Rahman, Md. Nazrul Islam, Md. Jafar Ullah, and Nirod Chandra Sarker

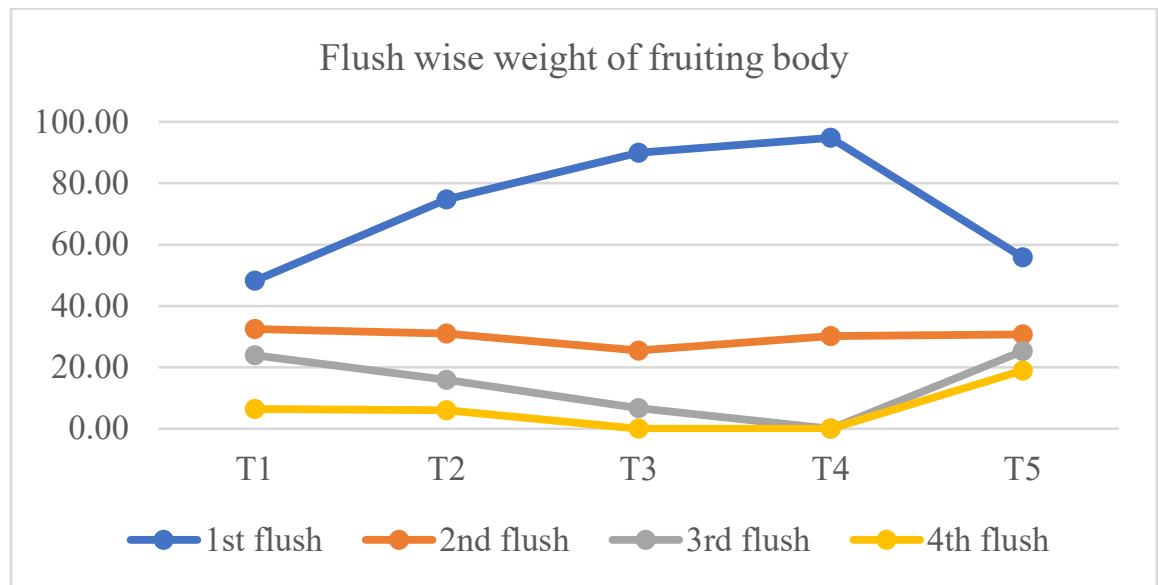

Figure 1: Flush wise weight of fruiting body as affected by casing material management technique

\section{CONCLUSION}

From the above study it can be concluded that casing material management technique influences the yield and yield attributes of milky white mushroom. Among different technique, removal of dried non effective fruiting bodies and filling the casing hole with fresh casing material after each harvest was the best technique for casing material management as it helps to produce highest economic yield and biological efficiency of milky white mushroom.

\section{SOURCES OF FUNDING}

This research received no specific grant from any funding agency in the public, commercial, or not-for-profit sectors.

\section{CONFLICT OF INTEREST}

The author have declared that no competing interests exist.

\section{ACKNOWLEDGMENT}

None.

\section{REFERENCES}

[1] Amin, R., Khair, A., Alam, N. and Lee, T. S. 2010. Effect of Different Substrates and Casing Materials on the Growth and Yield of Calocybe indica. Mycobiology, 38(2): 97-101.

[2] Farsi, M., Malekzadeh K. and Jalalzadeh, B. 2011. Recycling of mushroom peat casing soil through plastic mesh. Proceedings of the 7th International Conference on Mushroom Biology and Mushroom Products (ICMBMP7).

[3] Kerketta, A., Singh, H.K and Shukla, C.S. 2018. Cultivation of milky mushroom collected from different region of Chhattisgarh state. International Journal of Chemical Studies. 6(1): 1418-1421.

[4] Pani, B. K. 2012. Sporophore production of milky mushroom (Calocybe indica) as influenced by depth and time of casing. Intl J Adv Biol Res, 2(1): 168-170.

[5] Patel, P. and Trivedi, R. 2016. Yield Performance of Calocybe indica on Different Agricultural Subatrate. International Research Journal of Engineering, IT and Scientific Research. 2(3):105-111.

[6] Suess, A. and Curtis, J. 2009. Report: Value added strategies for spent mushroom substrate in BC. Prepared for British Columbia Mushroom Industry, 2006, http://www.agf.gov.bc.ca/mushroom/guide/value_added_ strategies.pdf

[7] Tukey, J. W. 1977. Exploratory data analysis. Addision-Wesley, Reading, PA. 